\title{
Nursing workload and occurrence of adverse events in intensive care: a systematic review*
}

\author{
Carga de trabalho de enfermagem e ocorrência de eventos \\ adversos na terapia intensiva: revisão sistemática \\ Carga laboral de enfermería y ocurrencia de eventos adversos \\ en los cuidados intensivos: revisión sistemática
}

\author{
Andrea Carvalho de Oliveira ${ }^{1}$, Paulo Carlos Garcia², Lilia de Souza Nogueira ${ }^{3}$
}

How to cite this article:

Oliveira AC, Garcia PC, Nogueira LS. Nursing workload and occurrence of adverse events in intensive care: a systematic review. Rev Esc Enferm USP. 2016;50(4):679-689. DOI: http://dx.doi.org/10.1590/S0080-623420160000500020

\begin{abstract}
* Extracted from the final residency report "Carga de trabalho de enfermagem e ocorrência de eventos adversos na terapia intensiva: revisão sistemática”, Programa de Residência em Enfermagem na Saúde do Adulto e do Idoso, Escola de Enfermagem/ Hospital

Universitário, Universidade de São Paulo, 2016.

${ }^{1}$ Universidade de São Paulo, Escola de Enfermagem, Programa de Residência em Enfermagem na Saúde do Adulto e do Idoso, São Paulo, SP, Brazil.

${ }^{2}$ Universidade de São Paulo, Hospital Universitário, Unidade de Terapia Intensiva Adulto, São Paulo, SP, Brazil.

${ }^{3}$ Universidade de São Paulo, Escola de Enfermagem, Departamento de Enfermagem Médico-Cirúrgica, São Paulo, SP, Brazil.
\end{abstract}

\begin{abstract}
Objective: To identify evidences of the influence of nursing workload on the occurrence of adverse events (AE) in adult patients admitted to the intensive care unit (ICU). Method: A systematic literature review was conducted in the databases MEDLINE, CINAHL, LILACS, SciELO, BDENF, and Cochrane from studies in English, Portuguese, or Spanish, published by 2015. The analyzed AE were infection, pressure ulcer (PU), patient falls, and medication errors. Results: Of 594 potential studies, eight comprised the final sample of the review. The Nursing Activities Score (NAS; 37.5\%) and the Therapeutic Intervention Scoring System (TISS; 37.5\%) were the instruments most frequently used for assessing nursing workload. Six studies (75.0\%) identified the influence of work overload in events of infection, PU, and medication errors. An investigation found that the NAS was a protective factor for PU. Conclusion: The nursing workload required by patients in the ICU influenced the occurrence of $\mathrm{AE}$, and nurses must monitor this variable daily to ensure proper sizing of staff and safety of care.
\end{abstract}

\section{DESCRIPTORS}

Workload; Nursing, Team; Patient Safety; Intensive Care Unit; Review. 


\section{INTRODUCTION}

A major challenge for managers in the hospital setting is to ensure patient safety, and one should consider the investigation of adverse events (AE) in the analysis of indicators of quality of care. In the intensive care unit (ICU), a department for the care of critically ill patients ${ }^{(1)}$, there is a higher probability of occurrence of adverse events due to clinical instability of patients and the high number of interventions and devices to which they are subjected during treatment ${ }^{(2)}$.

The occurrence of $\mathrm{AE}$ is to be discussed as one of the aspects that negatively impact patient safety, especially since 1999, with the release of the report To Err is Human by the Institute of Medicine (IOM). This report was based on the evaluation of the incidence of $\mathrm{AE}$ that occurred in three hospitals in the United States of America (USA) that found that approximately 100,000 people die in USA hospitals every year, victims of $\mathrm{AE}$, with a consequent significant increase in healthcare costs ${ }^{(3)}$.

Five years after the publication of this report, the World Health Organization (WHO) created the World Alliance for Patient Safety, which highlighted the main aspects of patient safety and the factors that can influence it, such as AE. According to the WHO's definition, incidents are events or circumstances which may result or have resulted in unnecessary harm to the patient, whereas $\mathrm{AE}$ are incidents arising from unintentional mistakes that cause measurable lesions ${ }^{(4)}$.

In 2013, the National Program of Patient Safety (PNSP, in Portuguese) was established in Brazil by the Ministry of Health, elaborating and implementing a set of basic protocols in health institutions ${ }^{(5)}$. Ordinance No. 1,377 adopted on July 9,2013, sets protocols for safe surgery, hand hygiene practices, and pressure ulcer avoidance ${ }^{(6)}$. After a few months, a new ordinance was published (Ordinance No. 2,095, September 24, 2013) setting new protocols: prevention of falls, safety in prescribing and in the use and administration of medications, as well as in patient identification ${ }^{(7)}$. These protocols act as guides, setting standards that must be used in hospitals and support best practices with a focus on patient safety ${ }^{(7)}$.

In the intensive care environment, the quality of nursing care and patient safety depends not only on the qualification of professionals, but also on the appropriate quota of human resources available. However, health services still face extreme difficulty in matching the number of professionals with the demand, generally due to financial issues. The numerical and qualitative mismatch between human resources and the care required by patients in intensive care can lead to work overload and failures in the process of care ${ }^{(8)}$.

Nursing workload can be defined as "work process elements that interact dynamically with each other and with the body of the worker, generating a process of adaptation which leads to wear" ${ }^{\text {(9). }}$. Acknowledging this load in the workplace is essential, since it is subject to control and reduction of undesirable effects ${ }^{(10)}$. However, ignoring the importance of its measurement may cause a negative impact on the quality and safety of care to patients, due to the greater likelihood of $\mathrm{AE}$.

Therefore, the assessment of nursing workload is a subject of great relevance, insofar as an oversized team implies higher costs. On the other hand, it is known that a reduced team can cause a drop in effectiveness and/or quality of care, extending the length of hospital stay and generating greater costs of treatment, in addition to exposing patients, staff, and the institution itself to the risk of not having safe care ${ }^{(11-12)}$.

Studies show that an increase in hours of nursing care provided to patients is associated with a decrease in the occurrence of $\mathrm{AE}$, such as: urinary tract infection; pressure ulcers; hospital-acquired pneumonia; wound infections; complications in central venous access; shock; thrombosis; medication errors; and postoperative complications ${ }^{(13-14)}$. Another publication shows that the nursing workload is a risk factor for death in the ICU ${ }^{(15)}$. However, no systematic reviews were identified from the literature showing a possible relationship between workload and $\mathrm{AE}$ in the scope of nursing.

In this context, the authors inquire: Is there an influence of nursing workload on the incidence of $A E$ in patients admitted to the ICU? The answer to this question may provide contributions to intensive care managers and nurses in the use of nursing workload measurement tools in order to justify the appropriate staff size in intensive care, ensuring care safety. The objective of the present review was to find evidence of the influence of nursing workload on the occurrence of $\mathrm{AE}$ (pressure ulcers, infection, falls, or medication errors) in adult patients admitted to the ICU.

\section{METHOD}

This is a systematic literature review, which consists of a rigorous synthesis of relevant results on a given theme, in which the main goal is to indicate the best available evidence on the effect of a particular therapy or intervention, so that professionals are aware of the best practices described in the literature ${ }^{(16)}$.

Data were collected through electronic search from October to November 2015 in the following databases: the Medical Literature Analysis and Retrieval System Online (MEDLINE); the Cumulative Index to Nursing and Allied Health Literature (CINAHL); the Latin American and Caribbean Center on Health Sciences Information (LILACS); the database of nursing (BDENF); and the Cochrane library. The portal Scientific Electronic Library Online (SciELO) was also analyzed. In addition, grey literature was analyzed through Google Scholar and a manual search was undertaken from the references cited in the articles selected.

Adverse events analyzed in this review include pressure ulcers, infections, falls, and medication errors. These events were selected from the proposal of the basic protocols previously described $^{(6-7)}$.

The PICO strategy (which is an acronym for Patient, Intervention, Comparison, and Outcomes) ${ }^{(17)}$, was used for the elaboration of the main question in this research. In order to find relevant studies that would respond to the study question, indexed and non-indexed descriptors (keywords) were used in Portuguese, English, and Spanish. The descriptors were obtained from the Medical Subject Headings (MESH), the Health Sciences Descriptors (DeCS, in Portuguese), and CINAHL titles, as shown in the following chart. 
Chart 1 - Elements of the PICO strategy, descriptors (MESH, DeCS and CINAHL titles) and keywords used - São Paulo, SP, Brazil, 2016.

\begin{tabular}{|c|c|c|c|c|}
\hline Elements & MESH & DeCS & CINAHL Titles & Keywords \\
\hline $\begin{array}{l}\mathbf{P} \\
\text { Patients in intensive } \\
\text { care units }\end{array}$ & $\begin{array}{c}\text { "Intensive Care" } \\
\text { "Intensive Care-Units" } \\
\text { "Critical Care-Nursing" } \\
\text { "Respiratory Care Units" } \\
\text { "Coronary Care Units" } \\
\text { "Burn Units" } \\
\text { "Critical Care" }\end{array}$ & $\begin{array}{c}\text { "Unidade de Terapia Intensiva" } \\
\text { "Terapia Intensiva" } \\
\text { "Unidade de Cuidados } \\
\text { Coronarianos" } \\
\text { "Unidade de Cuidados } \\
\text { Respiratórios" } \\
\text { "Unidade de Queimados" } \\
\text { "Enfermagem de Cuidados Críticos" } \\
\text { "Cuidados Críticos" }\end{array}$ & $\begin{array}{l}\text { "Intensive Care Units" } \\
\text { "Critical Care Nursing" } \\
\text { "Respiratory Care Units" } \\
\text { "Coronary Care Units" } \\
\text { "Burn Units" } \\
\text { "Critical Care" } \\
\text { "Stroke Units" } \\
\text { "Post Anesthesia Care } \\
\text { Units" }\end{array}$ & $\begin{array}{c}\text { "ICU" } \\
\text { "UTI" } \\
\text { "Intensive Care" } \\
\text { "Intensive Care Units" } \\
\text { "Critical Care Nursing" } \\
\text { "Respiratory Care Units" } \\
\text { "Coronary Care Units" } \\
\text { "Burn Units" } \\
\text { "Critical Care" } \\
\text { "Stroke Units" } \\
\text { "Post Anesthesia Care } \\
\text { Units" }\end{array}$ \\
\hline I & "Workload" & "Carga de trabalho" & $\begin{array}{l}\text { "Workload" } \\
\text { "Nurse-Patient Ratio" }\end{array}$ & $\begin{array}{c}\text { "Nursing workload" } \\
\text { "Nurse patient ratio" } \\
\text { "Workload" }\end{array}$ \\
\hline $\mathrm{C}$ & - & - & - & - \\
\hline $\begin{array}{c}\mathbf{O} \\
\text { Patient safety } \\
\text { (adverse events) }\end{array}$ & $\begin{array}{c}\text { "Patient Safety" } \\
\text { "Safety" } \\
\text { "Safety" "Management" } \\
\text { "latrogenic Disease" } \\
\text { "Cross-Infection" } \\
\text { "Pressure Ulcer" } \\
\text { "Accident Falls" } \\
\text { "Medication Errors" } \\
\text { "Medication Systems" } \\
\text { "Urinary tract Infections" } \\
\text { "Catheter-related } \\
\text { Infections" }\end{array}$ & $\begin{array}{l}\text { "Segurança do Paciente" } \\
\text { "Segurança" } \\
\text { "Gestão da Segurança" } \\
\text { "Doença latrogênica" } \\
\text { "Infecção" } \\
\text { "Infecção Hospitalar" } \\
\text { "Úlcera por Pressão" } \\
\text { "Erros de Medicação" } \\
\text { "Acidentes por Quedas" }\end{array}$ & $\begin{array}{c}\text { "Patient Safety" } \\
\text { "Adverse Health Care } \\
\text { Event" } \\
\text { "Health Care Errors" } \\
\text { "Iatrogenic Disease" } \\
\text { "Infection" } \\
\text { "Cross-Infection" } \\
\text { "Pressure Ulcer" } \\
\text { "Accident Falls" } \\
\text { "Medication Errors" } \\
\text { "Medication Systems" } \\
\text { "Urinary tract } \\
\text { Infections" } \\
\text { "Catheter-related } \\
\text { Infections" }\end{array}$ & $\begin{array}{l}\text { "Adverse Events" } \\
\text { "Evento Sentinela" } \\
\text { "Eventos Adversos" } \\
\text { "Patient Safety" } \\
\text { "Safety" } \\
\text { "Safety Management" } \\
\text { "Iatrogenic Disease" } \\
\text { "Health Care Errors" } \\
\text { "Adverse Health Care } \\
\text { Event" } \\
\text { "Fall" } \\
\text { "Urinary tract Infections" } \\
\text { "Catheter-related } \\
\text { Infections" } \\
\text { "Cross-Infection" } \\
\text { "Pressure Ulcer" } \\
\text { "Accident Falls" } \\
\text { "Medication Errors" } \\
\text { "Medication Systems" } \\
\text { "Catheter-related } \\
\text { bloodstream infections" } \\
\text { "Quedas" }\end{array}$ \\
\hline
\end{tabular}

The element $\mathrm{C}$ from the PICO strategy has not been addressed in this research, as this is not intended to compare interventions. The keywords (MESH and DeCS) and the titles from CINAHL were combined with the Boolean operators "OR" and "AND." The following criteria were used to guide the inclusion of articles in the review: studies published in full in national and international journals in English, Portuguese, or Spanish and which make use of instruments for measuring the workload of nursing in adult patients in the ICU. No filters were applied to the period of publication of the articles. Research on pediatric populations, as well as journal editorials, letters to the editor, comments, theses, and dissertations were excluded from the sample.

Considering the singularities and distinctive features of the databases, the search was carried out using different strategies, as described in Chart 2.

Chart 2 - Search strategies used in the databases MEDLINE, CINAHL, LILACS, SciELO, BDENF and Cochrane - São Paulo, SP, Brazil, 2016.

\begin{tabular}{|c|c|}
\hline Database & Search strategies \\
\hline MEDLINE (via PubMed) & $\begin{array}{l}\text { ("Intensive Care" [Mesh] OR "Intensive Care" OR "Intensive Care Units" [Mesh] OR "Intensive Care Units" } \\
\text { OR "Post-Anesthesia Care Units" OR "Stroke Units" OR "Critical Care Nursing" [Mesh] OR "Critical Care } \\
\text { Nursing" OR "Respiratory Care Units" [Mesh] OR "Respiratory Care Units" OR "Coronary Care Units" } \\
\text { [Mesh] OR "Coronary Care Units" OR "Burn Units" [Mesh] OR "Burn Units" OR "Critical Care" [Mesh] } \\
\text { OR "Critical Care" OR "ICU" OR "ICUs") AND ("Workload" [Mesh] OR "Workload" OR "Nursing Work- } \\
\text { load" OR "Nurse-patient ratio") AND "Patient Safety" [Mesh] OR "Patient Safety" OR "Safety" [Mesh] OR } \\
\text { "Safety" OR "Safety Management" [Mesh] OR "Safety Management" OR "Adverse Events" OR "Iatrogenic } \\
\text { Disease" [Mesh] OR "Iatrogenic Disease" OR "Adverse Health Care Event" OR "Health Care Errors" OR } \\
\text { "Infection" [Mesh] OR "Infection" OR "Cross Infection" [Mesh] OR "Cross" OR "Urinary Tract Infections, } \\
\text { Catheter-Related" OR "Catheter-Related Infections" [Mesh] OR "Catheter-Related Infections" OR "Catheter- } \\
\text { Related Bloodstream Infections" OR "Pressure Ulcer" [Mesh] OR "Pressure Ulcer" OR "Fall" OR "Accidental } \\
\text { Fall" [Mesh] OR "Accidental Falls" OR "Medication Errors" [Mesh] OR "Medication Errors" OR "Medication } \\
\text { Systems" [Mesh] OR "Medication Systems") }\end{array}$ \\
\hline
\end{tabular}




\begin{tabular}{|c|c|}
\hline Database & Search strategies \\
\hline CINAHL & $\begin{array}{l}\text { (MH "Intensive Care Units") OR "Intensive Care Units OR (MH "Critical Care Nursing") OR" Critical Care Nurs- } \\
\text { ing" OR (MH "Respiratory Care Units") OR "Respiratory Care Units" OR ("Coronary Care Units-MH") OR } \\
\text { "Coronary Care Units" OR (MH "Burn Units") OR "Burn Units" OR (MH "Critical Care") OR "Critical Care" } \\
\text { OR (MH "Stroke Units") OR "Stroke Units" OR (MH "Post Anesthesia Care Units") OR "Post Anesthesia Care } \\
\text { Units" OR "Intensive Care" OR "ICU" AND (MH "Wrkload") OR "Workload" OR (MH "Nurse-Patient Ratio") } \\
\text { OR "Nurse-Patient Ratio" Or "Nursing Workload" AND (MH "Patient Safety") OR "Patient Safety" OR (MH } \\
\text { "Adverse Health Care Event") OR "Adverse Health Care Event" OR (MH "Health Care Errors") OR "Health } \\
\text { Care Errors" OR (MH "Iatrogenic Disease") OR "latrogenic Disease" OR "Adverse Events" OR (MH "Safety") } \\
\text { OR "Safety" OR (MH "Infection") OR "Infection" OR (MH "Cross Infection") OR "Cross" OR "Infection" } \\
\text { ("Urinary Tract Infections MH, Catheter-Related") OR "Urinary Tract Infections, Catheter-Related" OR (MH } \\
\text { "Catheter-Related Infections") OR "Catheter-Related Infections" OR (MH "Catheter-Related Bloodstream Infec- } \\
\text { tions") OR "Catheter-Related Bloodstream Infections" OR (MH "Pressure Ulcer") OR "Pressure Ulcer" OR (MH } \\
\text { "Accidental Falls") OR "Accidental Falls" OR "Fall" OR (MH "Medication Errors") OR "Medication Errors" OR } \\
\text { (MH "Medication Systems") OR "Medication Systems") }\end{array}$ \\
\hline LILACS & $\begin{array}{l}\text { ("Unidade de terapia intensiva" OR "Terapia intensiva" OR "Unidades de cuidados coronarianos" OR } \\
\text { "Unidades de cuidados respiratórios" OR "Unidade de queimados" OR "Enfermagem de cuidados críticos" } \\
\text { OR "Cuidados críticos" OR "UTI") AND ("Carga de Trabalho") AND ("Segurança do paciente" OR "Segu- } \\
\text { rança" OR "Gestão de segurança" OR "Doença iatrogênica" OR "Evento Sentinela" OR "Eventos adversos" } \\
\text { OR "Infecção" OR "Infecção hospitalar" OR "Úlcera por pressão" OR "Erros de medicação" OR "Aciden- } \\
\text { tes por quedas" OR "Quedas") }\end{array}$ \\
\hline SciElO & $\begin{array}{l}\text { ("Unidade de terapia intensiva" OR "Terapia intensiva" OR "Unidades de cuidados coronarianos" OR } \\
\text { "Unidades de cuidados respiratórios" OR "Unidade de queimados" OR "Enfermagem de cuidados críticos" } \\
\text { OR "Cuidados críticos" OR "UTI") AND ("Carga de Trabalho") AND ("Segurança do paciente" OR "Segu- } \\
\text { rança" OR "Gestão de segurança" OR "Doença iatrogênica" OR "Evento Sentinela" OR "Eventos adversos" } \\
\text { OR "Infecção" OR "Infecção hospitalar" OR "Úlcera por pressão" OR "Erros de medicação" OR "Aciden- } \\
\text { tes por quedas" OR "Quedas") }\end{array}$ \\
\hline BDENF & $\begin{array}{l}\text { ("Unidade de terapia intensiva" OR "Terapia intensiva" OR "Unidades de cuidados coronarianos" OR } \\
\text { "Unidades de cuidados respiratórios" OR "Unidade de queimados" OR "Enfermagem de cuidados críticos" } \\
\text { OR "Cuidados críticos" OR "UTI") AND ("Carga de Trabalho") AND ("Segurança do paciente" OR "Segu- } \\
\text { rança" OR "Gestão de segurança" OR "Doença iatrogênica" OR "Evento Sentinela" OR "Eventos adversos" } \\
\text { OR "Infecção" OR "Infecção hospitalar" OR "Úlcera por pressão" OR "Erros de medicação" OR "Aciden- } \\
\text { tes por quedas" OR "Quedas") }\end{array}$ \\
\hline Cochrane & $\begin{array}{l}\text { (MH "Intensive Care Units" OR MH "Critical Care" OR MH "Critical Care Nursing" OR MH "Respiratory } \\
\text { Care Units" OR MH "Coronary Care Units" OR MH "Burn Units") AND MH "Workload" AND (MH "Patient } \\
\text { Safety" OR MH "Accidental Falls" OR MH "Pressure Ulcer" OR MH "Medication Errors" OR MH "Cross Infec- } \\
\text { tion" OR "Adverse Events" OR MH "Safety" OR MH "Safety Management" OR MH "Iatrogenic Disease" OR } \\
\text { MH "Medication Systems" OR MH "Urinary Tract Infections" OR MH "Catheter-Related Infections") }\end{array}$ \\
\hline
\end{tabular}

Studies retrieved from the search strategy had their title and abstract evaluated, so as to identify those pertinent to the subject at hand. In studies where the given data were not enough to determine whether or not they should be included, the study in question was considered for the shortlist, so as to avoid mistaken exclusions.

Preselected studies were recovered in their entirety and analyzed independently by two researchers. In the case of disagreement between them, a third researcher conducted an analysis of the research, so as to ensure the prevailing opinion of the majority.

To extract the data from the articles, we used an instrument containing the following information: title; author; journal; year and country of publication; research objectives; methodological design; measuring instrument of nursing workload used; type of adverse event analyzed; main results; and conclusions.

To assess the quality of the studies included in the review, two researchers independently applied the instrument Strengthening the Reporting of Observational Studies in
Epidemiology (STROBE), which consists of a checklist with 22 items about recommendations on what should be included in a more accurate and complete description of observational studies ${ }^{(18)}$. It should be noted that this analysis was carried out not for the purpose of exclusion, but for description of sample studies.

Due to the heterogeneity of the methodology of the studies included in the review, it was not possible to perform meta-analysis.

\section{RESULTS}

From the search strategy employed, 596 potential studies were recovered, with the largest number of studies found in the MEDLINE database $(\mathrm{n}=345)$, followed by CINAHL $(n=226), \operatorname{LILACS}(n=14), \operatorname{BDENF}(n=6), \operatorname{SciELO}(n=3)$, and Cochrane $(\mathrm{n}=2)$.

Figure 1 presents the process of study selection. Only eight of 37 studies preselected for reading in full met the eligibility criteria of this review and comprised the final sample. 


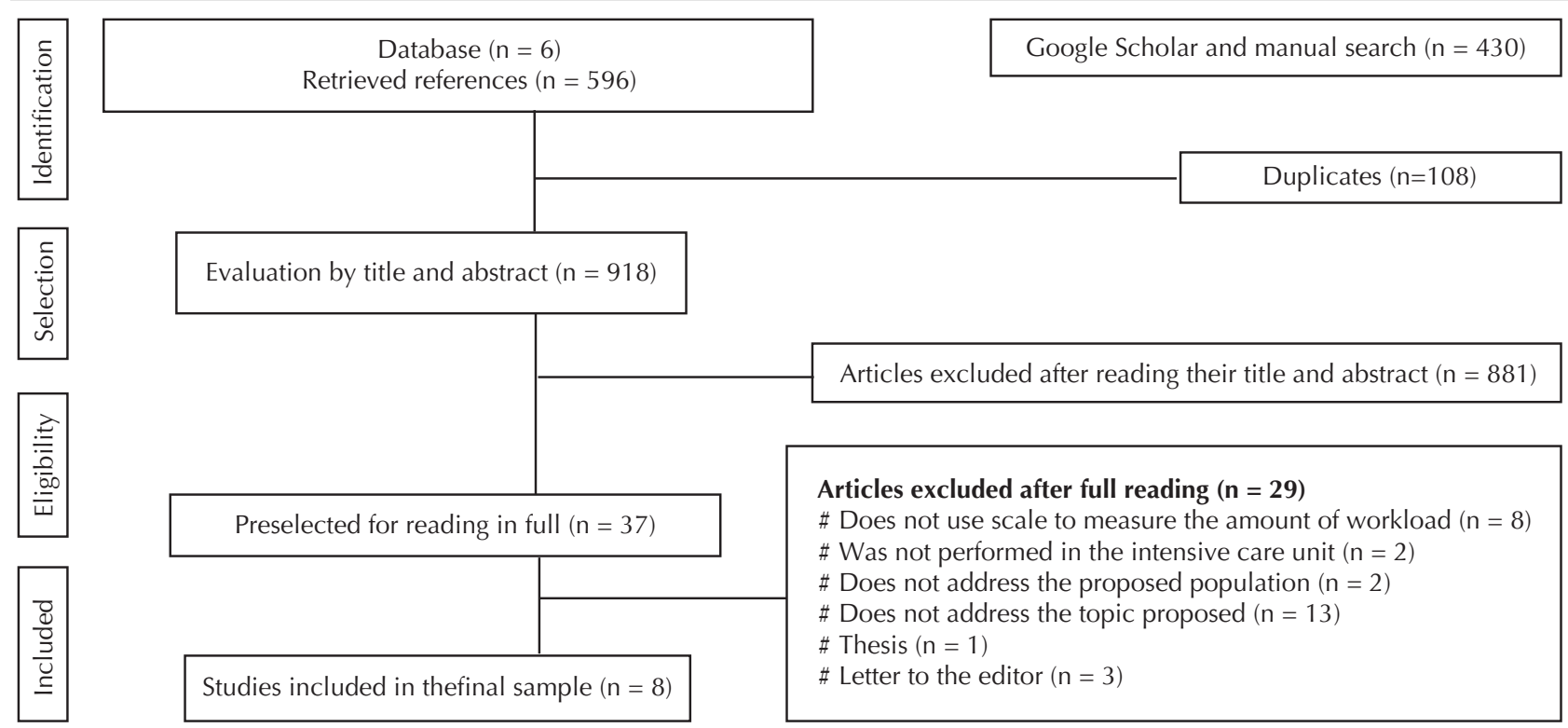

Figure 1 - Flowchart of the process of study selection - São Paulo, SP, Brazil, 2016.

Chart 3 - Distribution of studies according to title, objective, design, country and year of publication - São Paulo, SP, Brazil, 2016.

\begin{tabular}{|c|c|c|c|c|}
\hline $\begin{array}{c}\text { Identification of study } \\
\text { and number of items in } \\
\text { the STROBE }\end{array}$ & Title & Objective & Study design & Country, year \\
\hline Study 1 (E1) STROBE: 12 & $\begin{array}{c}\text { Relación entre carga laboral } \\
\text { e incidentes en una unidad } \\
\text { de cuidados intensivos } \\
\text { polivalente }\end{array}$ & $\begin{array}{c}\text { Check the relationship between } \\
\text { workload and the occurrence of } \\
\text { incidents in the ICU, including } \\
\text { risk of death }\end{array}$ & $\begin{array}{l}\text { Prospective, cohort } \\
\text { study }\end{array}$ & Chile, 2005 \\
\hline Study 2 (E2) STROBE: 14 & $\begin{array}{l}\text { Propagation of methicillin- } \\
\text { resistant Staphylococcus } \\
\text { aureus due to the overloading } \\
\text { of medical nurses in intensive } \\
\text { care units }\end{array}$ & $\begin{array}{l}\text { Investigate whether the workload } \\
\text { of nursing staff is related to the } \\
\text { development of infections by } \\
\text { Methicillin-resistant Staphylococcus } \\
\text { aureus }\end{array}$ & $\begin{array}{l}\text { Prospective cohort } \\
\text { study }\end{array}$ & Slovenia, 2006 \\
\hline Study 3 (E3) STROBE: 15 & $\begin{array}{l}\text { Multiresistant bacterial } \\
\text { colonization due to increased } \\
\text { nurse workload in the } \\
\text { neurology intensive care unit }{ }^{(21)}\end{array}$ & $\begin{array}{c}\text { Determine the relationship between } \\
\text { nursing workload and coloniza- } \\
\text { tion or infection by multiresistant } \\
\text { bacteria (BMR) }\end{array}$ & $\begin{array}{c}\text { Prospective, } \\
\text { observational study }\end{array}$ & $\begin{array}{l}\text { Turke, } \\
2016\end{array}$ \\
\hline Study 4 (E4) STROBE: 19 & $\begin{array}{l}\text { Adverse drug events in } \\
\text { intensive care units: a } \\
\text { cross-sectional study of } \\
\text { prevalence and risk factors }{ }^{(22)}\end{array}$ & $\begin{array}{l}\text { Characterize the occurrence of } \\
\text { adverse events related to medicines } \\
\text { and to investigate the factors that } \\
\text { influence the occurrence of these } \\
\text { events in an ICU }\end{array}$ & $\begin{array}{c}\text { Retrospective } \\
\text { cross-sectional study }\end{array}$ & Belgium, 2011 \\
\hline Study 5 (E5) STROBE: 19 & $\begin{array}{l}\text { Nursing workload the risk } \\
\text { factor for healthcare } \\
\text { associated infections in ICU: } \\
\text { prospective study }\end{array}$ & $\begin{array}{l}\text { Evaluate the role of nursing } \\
\text { workload on occurrence of } \\
\text { infections associated with assistance } \\
\text { in intensive care units }\end{array}$ & $\begin{array}{l}\text { Prospective, cohort } \\
\text { study }\end{array}$ & Brazil, 2012 \\
\hline Study 6 (E6) STROBE: 19 & $\begin{array}{c}\text { Pressure ulcers in the intensive } \\
\text { care unit: the relationship } \\
\text { between nursing workload, } \\
\text { illness severity and pressure } \\
\text { ulcer risk }\end{array}$ & $\begin{array}{l}\text { Check the association between } \\
\text { pressure ulcer development, nursing } \\
\text { workload and severity of patient } \\
\text { status }\end{array}$ & $\begin{array}{c}\text { Prospective } \\
\text { descriptive study }\end{array}$ & Brazil, 2013 \\
\hline Study 7 (E7) STROBE: 19 & $\begin{array}{l}\text { Nursing workload and } \\
\text { occurrence of incidents and } \\
\text { adverse events in } \\
\text { ICU patients }{ }^{(25)}\end{array}$ & $\begin{array}{l}\text { Verify the influence of nursing } \\
\text { workload on the occurrence of } \\
\text { incidents without injury and } \\
\text { adverse events in ICU }\end{array}$ & $\begin{array}{l}\text { Prospective, cohort } \\
\text { study }\end{array}$ & Brazil, 2014 \\
\hline Study 8 (E8) STROBE: 16 & $\begin{array}{l}\text { Bacterial colonization due to } \\
\text { increased nurse workload in } \\
\text { an intensive care unit }{ }^{26)}\end{array}$ & $\begin{array}{l}\text { Determine the possible association } \\
\text { between the risk of hospital-ac- } \\
\text { quired infections and increasing the } \\
\text { daily workload of nursing staff }\end{array}$ & Retrospective study & Turkey, 2015 \\
\hline
\end{tabular}


None of the studies in Chart 3 showed agreement with all items of the STROBE. However, all of the research in this review has included at least $50 \%$ of the items. Of the eight studies included in the review, three (37.5\%) were carried out in Brazil ${ }^{(23-25)}$ and two (25.0\%) in Turkey ${ }^{(21,26)}$. Chile $^{(19)}$, Slovenia ${ }^{(20)}$, and Belgium ${ }^{(22)}$ contributed with one study each (12.5\%).

The searches were performed between 2000 and 2013 and published between 2005 and 2015 in English ${ }^{(20,22,24)}$, Spanish ${ }^{(19)}$, Portuguese ${ }^{(25)}$ or in all three languages: English, Spanish and Portuguese ${ }^{(21,26)}$. A total of six studies (75.0\%) were published in international journals ${ }^{(19-24)}$ and two $(25.0 \%)$ in national journals ${ }^{(25-26)}$. There has been a higher percentage of prospective studies $(75.0 \%)^{(19-21,23-25)}$, especially of the cohort type ${ }^{(19-20,23-25)}$. Retrospective investigations were performed less frequently $(25.0 \%)^{(22,26)}$.

Chart 4 shows that the sample analyzed in the searches ranged from 79 to 970 patients in the $\operatorname{ICU}^{(19-26)}$. Of the studies that described the characteristics of patients in the results ${ }^{(21-24,26)}$, it was possible to identify the prevalence of

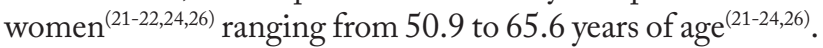
Regarding the instrument of workload applied, three studies (37.5\%) used the Nursing Activities Score (NAS) ${ }^{(23-25)}$, three (37.5\%) the Therapeutic Intervention Scoring System (TISS), either the original ${ }^{(20)}$ or the version with 28 items $^{(19,22)}$, and two (25.0\%), the Omega Scoring System (Omega) and the Project de Recherché en Nursing $(\mathrm{PRN})^{(21,26)}$.

Regarding the types of AE, healthcare-associated infections (HAI) were examined in five studies $(62.5 \%)^{(19-21,23,26)}$. Occurrence of pressure ulcer ${ }^{(24-25)}$ was a less frequently investigated $\mathrm{AE}(25.0 \%)$, as was medication error $(25.0 \%)^{(22,25)}$. Adverse events involving accidental loss of central venous catheter, obstruction or loss of the nasogastric tube, loss or damage to the endotracheal tube cuff, loss of bloodline, and falls were also considered as $\mathrm{AE}$ in the Chilean study and were referred to as sentinel incidents by the authors ${ }^{(19)}$.

Most of the eight studies included in the review found an influence of nursing workload on the occurrence of different AE: infection ${ }^{(20-21,23,26)}$, pressure ulcer ${ }^{(25)}$, and drug use $^{(22,25)}$. A Brazilian study that analyzed the occurrence of pressure ulcers in intensive care concluded that nursing workload was a protective factor for the outcome $\mathrm{e}^{(24)}$. A study showed that the TISS-28 exerted influence only on mortality, that is, there was no relationship between nursing workload and the occurrence of sentinel incidents, including falls or infections, in the ICU ${ }^{(19)}$.

Chart 4 - Characteristics of studies included in the review according to the sample and patients' characteristics, analyzed AE, applied instrument of nursing workload, results and influence of nursing workload on occurrence of AE - São Paulo, SP, Brazil, 2016.

\begin{tabular}{|c|c|c|c|c|c|}
\hline Study code & $\begin{array}{l}\text { Sample and } \\
\text { characteristics: } \\
\text { age - mean } \\
\text { (SD) and } \\
\text { gender (\%) }\end{array}$ & AE analyzed & $\begin{array}{l}\text { Instrument of } \\
\text { nursing } \\
\text { workload } \\
\text { Mean (SD) }\end{array}$ & Main results & $\begin{array}{l}\text { Influence } \\
\text { of nursing } \\
\text { workload on } \\
\text { the event of } \\
\text { infection, } \\
\text { PU, fall, or } \\
\text { medication } \\
\text { error? }\end{array}$ \\
\hline E1 & $\begin{array}{l}\mathrm{N}=144 \\
\text { Age: SI } \\
\text { Gender: SI }\end{array}$ & $\begin{array}{l}\text { Sentinel incidents (accidental loss } \\
\text { of central venous catheter, obstruc- } \\
\text { tion or loss of a nasogastric tube, } \\
\text { loss or damage to the endotracheal } \\
\text { tube cuff, loss of bloodline, or } \\
\text { falls), nosocomial infections (infec- } \\
\text { tions associated with the central } \\
\text { venous catheter or parenteral nutri- } \\
\text { tion, urinary tract infection related } \\
\text { to indwelling urinary catheter), and } \\
\text { death in the ICU }\end{array}$ & $\begin{array}{c}\text { TISS-28 } \\
47.4(9.7)\end{array}$ & $\begin{array}{c}\text { Occurrence of } 101 \mathrm{AE} \text { ( } 33 \text { deaths, } \\
27 \text { infections, } 14 \text { incidents, and } 27 \\
\text { pressure ulcers). There was a cor- } \\
\text { relation between the patients who } \\
\text { died in the ICU and TISS values } \\
\text { higher than } 54(\mathrm{p}=0.054) \text { and } 59 \\
\text { points }(\mathrm{p}=0.054) \text {. } \\
\text { There was no correlation between } \\
\text { the daily TISS and the risk of occur- } \\
\text { rence of other AE. }\end{array}$ & No \\
\hline E2 & $\begin{array}{l}\mathrm{N}=970 \\
\text { Age: } \mathrm{SI} \\
\text { Gender: SI }\end{array}$ & $\begin{array}{l}\text { Infections related to Staphylococ- } \\
\text { cus aureus resistant to methicillin } \\
\text { (MRSA) }\end{array}$ & $\begin{array}{c}\text { TISS } \\
188.9(67.74)= \\
\text { TISS mean by } \\
\text { nurse }\end{array}$ & $\begin{array}{l}144 \text { patients }(14.8 \%) \text { were admit- } \\
\text { ted to the ICU with positive MRSA } \\
\text { and } 47(4.84 \%) \text { acquired MRSA } \\
\text { during hospitalization. There was } \\
\text { occurrence of MRSA when the daily } \\
\text { TISS score exceeded } 150 \text {. Daily } \\
\text { transmission rate was } 0.15 \text {, with } \\
\text { mean daily TISS score above } 250, \\
0.05 \text { with TISS between } 201 \text { and } \\
250 \text {, and } 0.01 \text { with TISS between } \\
151 \text { and } 200 \text {. }\end{array}$ & Yes \\
\hline E3 & $\begin{array}{c}\mathrm{N}=138 \\
\text { Age: Women } \\
\text { 65.6 (6.7); } \\
\text { Men 62.2 } \\
\text { (15.8) } \\
\text { Gender: } 51.4 \% \\
\text { female }\end{array}$ & $\begin{array}{c}\text { Infections caused by multiresistant } \\
\text { bacteria (MRB) }\end{array}$ & $\begin{array}{c}\text { Omega/PRN } \\
\text { Omega: } 20(8.9) \\
\text { with MRB }+ \\
\text { and } 9 \text { (1.9) with } \\
\text { MRB- } \\
\text { PRN: (87) with } \\
\text { MRB + and (52) } \\
\text { with MRB- }\end{array}$ & $\begin{array}{c}\text { MRB were identified in } 26 \text { cultures } \\
(18.8 \%) \text {. There was a correlation be- } \\
\text { tween colonization or infection by } \\
\text { MRB and the length of stay, Omega } \\
2 \text {, Omega } 3 \text {, total Omega, total and } \\
\text { daily PRN }(p<0.05) \text {. Patients evalu- } \\
\text { ated by MRB demanded greater } \\
\text { nursing workload }(\mathrm{PRN}) \text { than those } \\
\text { without MRB }(p<0.001) \text {. }\end{array}$ & Yes \\
\hline
\end{tabular}




\begin{tabular}{|c|c|c|c|c|c|}
\hline Study code & $\begin{array}{l}\text { Sample and } \\
\text { characteristics: } \\
\text { age - mean } \\
\text { (SD) and } \\
\text { gender (\%) }\end{array}$ & AE analyzed & $\begin{array}{l}\text { Instrument of } \\
\text { nursing } \\
\text { workload } \\
\text { Mean (SD) }\end{array}$ & Main results & $\begin{array}{l}\text { Influence } \\
\text { of nursing } \\
\text { workload on } \\
\text { the event of } \\
\text { infection, } \\
\text { PU, fall, or } \\
\text { medication } \\
\text { error? }\end{array}$ \\
\hline E4 & $\begin{array}{c}\mathrm{N}=79 \\
\text { Age: } 65.3 \\
(12.8) \\
\text { Gender: } 77.2 \% \\
\text { female }\end{array}$ & $\begin{array}{l}\text { Damage or injury after medication } \\
\text { (AE related to medication) }\end{array}$ & $\begin{array}{l}\text { TISS-28 } \\
30.1(7.1)\end{array}$ & $\begin{array}{l}\text { There was a total of } 230 \mathrm{AE} \text { related } \\
\text { to medication, the most frequent } \\
\text { event being hypoglycemia as- } \\
\text { sociated with the use of an insulin } \\
\text { pump ( } 33 \% \text { ). The mean TISS- } 28 \text { was } \\
\text { significantly higher on days when } \\
\text { there were one or more AE than on } \\
\text { days without AE. }\end{array}$ & Yes \\
\hline E5 & $\begin{array}{c}\mathrm{N}=195 \\
\text { Age: with } \\
\text { infection } 56.2 \\
\text { (18.5); without } \\
\text { infection } 50.9 \\
\text { (19.8) } \\
\text { Gender: } 50.8 \% \\
\text { male }\end{array}$ & $\begin{array}{l}\text { Healthcare-associated infections } \\
\qquad(\mathrm{HAI})\end{array}$ & $\begin{array}{l}\text { NAS } \\
81.2(16.2) \text { with } \\
\text { HAl and } 66.7 \\
\text { (20.3) without } \\
\text { HAl }\end{array}$ & $\begin{array}{l}22 \% \text { of patients developed } \mathrm{HAI} \text { in } \\
\text { the ICU. The risk factors for patients } \\
\text { to acquire } \mathrm{HAI} \text { were: excessive } \\
\text { workload } \mathrm{NAS} \geq 51 \text { (OR } 11.41 ; \\
95 \% \mathrm{Cl} 1.49 ;-87.28 \text { ) and organic } \\
\text { dysfunction according to the SOFA } \\
\text { (OR } 1.13 ; 95 \% \mathrm{Cl} 1.02-1.24) \text {. }\end{array}$ & Yes \\
\hline E6 & $\begin{array}{l}\mathrm{N}=160 \\
\text { Age: } 55.5 \\
\quad(18.8) \\
\text { Gender: } 53.8 \% \\
\text { female }\end{array}$ & Occurrence of pressure ulcer (PU) & $\begin{array}{c}\text { NAS } \\
62.9(12.0)\end{array}$ & $\begin{array}{l}55 \text { patients }(34.4 \%) \text { developed PU. } \\
\text { There was a strong negative cor- } \\
\text { relation between NAS and Braden } \\
\text { scale }(r=0.61, p<0.01) \text {. The NAS } \\
\text { was a protective factor for the oc- } \\
\text { currence of PU (OR } 0.916 ; 95 \% \\
\mathrm{CI} 0.855-0.980) \text {, that is, patients } \\
\text { with a high nursing workload had a } \\
\text { lower chance of developing PU in } \\
\text { the ICU. }\end{array}$ & $\begin{array}{c}\text { Yes } \\
\text { (protection } \\
\text { factor) }\end{array}$ \\
\hline E7 & $\begin{array}{c}\mathrm{N}=380 \\
\text { Age: } \mathrm{SI} \\
\text { Gender: SI }\end{array}$ & $\begin{array}{l}\text { AE related to medication, dermati- } \\
\text { tis, } \mathrm{PU} \text {, errors in medical diagnosis } \\
\text { and treatment, fleabites, problems } \\
\text { with the containment of patients, } \\
\text { and mortality }\end{array}$ & $\begin{array}{c}\text { NAS } \\
69.55(1.40)- \\
\text { Hospital } 1 \\
61.97(1.40)- \\
\text { Hospital } 2\end{array}$ & $\begin{array}{l}\text { Of the } 399 \text { admissions, } 74.2 \% \text { had } \\
\text { undergone at least one AE during } \\
\text { stay in the ICU. Risk factors for the } \\
\text { occurrence of at least one nursing- } \\
\text { related AE were: length of stay } \\
\text { greater than three days (OR 10.63; } \\
95 \% \mathrm{Cl} 6.17-18.31 \text { ) and nursing } \\
\text { workload - NAS } \geq 51 \text { (OR } 3.21 ; 95 \% \\
\text { CI 1.78-5.79). }\end{array}$ & Yes \\
\hline E8 & $\begin{array}{l}\mathrm{N}=168 \\
\text { Age: Women } \\
-64.9(6.2) \\
\text { Men }-63.1 \\
\quad(11.9) \\
\text { Gender: } 54.2 \% \\
\quad \text { female }\end{array}$ & Infections caused by MRB & $\begin{array}{c}\text { Omega/PRN } \\
\text { Omega: } 21(9.1) \\
\text { with MRB }+ \text { and } \\
10.3(2.1) \text { with } \\
\text { MRB- } \\
\text { PRN: } 1519 \\
\text { (103) with MRB } \\
\text { + and } 719(52) \\
\text { with MRB- }\end{array}$ & $\begin{array}{l}39 \text { patients }(23.2 \%) \text { were identified } \\
\text { with MRB+. There was a correlation } \\
\text { between colonization or infection } \\
\text { by MRB and length of stay, Omega } \\
2 \text {, Omega 3, total Omega, total } \\
\text { and daily PRN }(p<0.05) \text {. Patients } \\
\text { evaluated by MRB demanded } \\
\text { greater nursing workload (accord- } \\
\text { ing to PRN) than those without } \\
\text { MRB }(p<0.001) \text {. }\end{array}$ & Yes \\
\hline
\end{tabular}

SI: No information; TISS: Therapeutic Intervention Scoring System; Omega: Omega Scoring System; PRN: Project de Recherché en Nursing; SOFA: Sequential Organ Failure Assessment; NAS: Nursing Activities Score; OR: Odds ratio; CI: Confidence interval.

\section{DISCUSSION}

From the full analysis of selected studies in this review $^{(19-26)}$, it was found that nursing workload influences the occurrence of $\mathrm{AE}$ in patients admitted to the ICU.

Regarding the instruments of measurement of nursing workload, there was a greater amount of studies that applied the NAS ${ }^{(23-25)}$ or the TISS ${ }^{(19-20,22)}$ in patients analyzed. The NAS, developed by Miranda et al. in 2003, is an instrument that analyzes 23 items (nursing activities), with scores ranging from a minimum weight of 1.2 to a maximum of 32.0. The total score is obtained by summing the points, and directly expresses the percentage of time spent by a professional of the nursing staff in the care of a patient in critical condition over 24 hours ${ }^{(27)}$. The NAS was translated and validated in Brazil by Queijo and Padilha in 2009 ${ }^{(12)}$.

Amongst the studies that used the NAS, all were carried out in Brazil and displayed mean values of nursing workload between $61.97 \%$ and $81.2 \%{ }^{(23-25)}$. These values are close to those of other studies that applied the NAS in Brazilian $\mathrm{ICU}^{(28-30)}$. However, when analyzing the mean NAS scores in relation to international studies, discrepant results are found: approximately 41\% NAS in Spanish studies ${ }^{(31-33)}$, but more than $95 \%$ in Norwegian research ${ }^{(33)}$. Among the contributing factors to the different findings between the national and international literature, one must consider the clinical characteristics of the patients, the specific features 
of the ICU, and the heterogeneity in the interpretation and application of the instrument.

Considering the minimum (61.97\%) and maximum (81.2\%) means of NAS found in this review and that 1 NAS point is equivalent to 14.4 minutes $^{(27)}$ of nursing care, it can be concluded that the patients analyzed in these studies $^{(23-25)}$ required minimal care of approximately 14.9 hours and maximum care of 19.5 hours in a period of 24 hours in intensive care. Comparing these values with those recommended by the resolution of the Federal Council of Nursing (Cofen-293/2004) ${ }^{(34)}$ which considers, for sizing purposes, 17.9 hours of care provided by the nursing team to a critical patient, the minimum mean percentage of NAS is within established parameters. However, for the maximum mean percentage, there is a possible work overload among nursing staff.

Instruments TISS or TISS-28, used in three studies $^{(19-20,22)}$, were precursors of the NAS. The TISS, created by Cullen et al. in 1974, was the pioneer measurement system of nursing workload. The TISS presupposed that the more serious the patient condition, the greater the number of interventions carried out, regardless of the diagnosis presented ${ }^{(35)}$. This instrument underwent various modifications and simplifications, and the latest version, the TISS-28, analyzes 28 items, divided into seven groups: basic activities, ventilatory support, cardiovascular support, renal support, neurologic support, and metabolic support, in addition to specific interventions. The variation of TISS-28 score is 1 to 78 points, each point of the score being equivalent to 10.6 minutes of care from a nurse to an ICU patient ${ }^{(36)}$.

The practical application of TISS-28 showed weaknesses, since activities related to indirect care to patients, such as administrative and managerial tasks, as well as family support, were not addressed. In order to fill this gap, the same group of researchers proposed the creation of the NAS in $2003^{(27)}$, as described earlier. It should be noted that both the TISS-28 and the NAS instruments were created from multi-center studies, with the participation of ICU staff from different countries and continents.

Omega and PRN were applied in two studies carried out in Turkey by the same group of researchers with the purpose of analyzing the relationship between colonization or infection by MRB and nursing workload ${ }^{(21,26)}$. The first scale was developed in Canada in $1981^{(37)}$ and, the second in France in $1986^{(38)}$. The use of instruments for measuring nursing workload developed in a single country can result in restrictions in application and generalization of results, because they reflect the characteristics of the population to whom these instruments were created.

Regarding the design of the studies, the majority was of the prospective type ${ }^{(19-21,23-25)}$. This type of method is more time consuming and costly, but has the advantage of presenting less bias, because variables such as lack of information can be controlled, allowing for more reliable results ${ }^{(39)}$. Prospectively collected data may explain the reduced time span of the studies (3 to 8 months) and, consequently, the small size of samples (138 to 3800$)^{(19-21,23-25)}$. Only one prospective study, conducted in an ICU with 11 beds in Slovenia ${ }^{(20)}$, examined patients admitted to the intensive care unit during three years, allowing the investigation of a larger number of patients $(n=970)$. One must take into account that small samples, often from a single ICU, may restrict the application of the results in other populations, because they represent the specific reality of the units evaluated.

Among the AE analyzed, HAI were the most frequently considered by researchers ${ }^{(19-21,23-26)}$. Such an interest may be justified by the fact that HAI are factors associated with extending length of hospital stay, generating high levels of health complications and increasing care costs, as well as favoring the selection and spread of multiresistant organisms ${ }^{(40)}$, making this event one of the focuses of interest of the PNSP. In this respect, the practice of hand hygiene, created with the aim of preventing and controlling HAI, defined the five major moments in which the hands must be sanitized as well as the technique itself ${ }^{(41)}$.

Of the five studies that analyzed these AE, most (80.0\%) identified that high workload is a risk factor for occurrence of $\mathrm{HAI}$ in intensive care ${ }^{(20-21,23,26)}$. Brazilian researchers stressed that HAI had an influence on the overload of nursing work, characterized by a NAS score equal to or greater than $51 \%$, because, in the units of study, each nursing professional provides care to two patients per shift ${ }^{(23)}$. In this respect, when analyzing the workload of nursing care required by patients, one must consider the number of professionals available to answer it, because this variable directly impacts the quality of care and occurrence of $\mathrm{AE}^{(42-43)}$. Only one investigation failed to identify the relationship between nursing workload and $\mathrm{HAI}^{(19)}$. The authors explain this finding, emphasizing that patients in more severe conditions require more care and are more closely monitoring in the ICU and therefore have greater protection against $\mathrm{AE}^{(19)}$.

The overload of nursing work also influenced the occurrence of AE related to medications ${ }^{(22,25)}$. Research conducted in the U.S. revealed that in the country's hospitals each patient admitted is susceptible to one medication error per day $^{(44)}$. In a Brazilian study performed in an ICU, of the 550 AE identified, 283 were related to medication errors ${ }^{(19-21,23-25)}$. It must be considered that this type of AE in the ICU can be fatal due to the severity of the clinical condition of the patient and the complexity of the drug therapy ${ }^{(46)}$.

The high incidence of this event became one of the focuses of the Ministry of Health which, together with the National Health Surveillance Agency (ANVISA, in Portuguese), launched a safety protocol on the prescription, use, and administration of medicines, indicating safe practices such as: confirming the patient's ID on the prescription; the use of the full name and date of birth; the signature and stamp of the prescriber; identification of allergies; dosage; titration; infusion speed; and route of administration of the drugs prescribed. In addition, the protocol recommends safe practices in relation to the storage and disposal of medicines ${ }^{(47)}$.

Although studies show that falls in the hospital environment are related to a lack of quality of care and have unforeseen consequences to the patient such as abrasions, contusions, lacerations, and fractures ${ }^{(48)}$, studies of this event in the ICU are limited. In this review, only one investigation 
addressed the topic ${ }^{(19)}$ and did not identify the influence of nursing workload on the occurrence of this AE. The scarcity of studies that address this AE in the ICU can be related to a low incidence of falls with injury to the patient in this type of unit, because continuous monitoring is one of the features of intensive care.

Despite investment in devices for the prevention and treatment of pressure ulcers in intensive care, there is still a high incidence of this event in patients hospitalized in critical care units $^{(49-51)}$. In this respect, two Brazilian investigations ${ }^{(24-25)}$ analyzed the possible influence of nursing workload on this AE and found contradictory results.

Research conducted in ICU of two public hospitals showed that there were 2,317 $\mathrm{AE}$ in 399 admissions occurred between May and August 2009, and dermatitis, diaper rash and pressure ulcers were the most frequent $(60.45 \%)$. In this study, patients with an NAS equal to or higher than $51.0 \%$ were about three times more likely to report at least one $\mathrm{AE}$ in the ICU than those with an NAS lower than 51\%. The authors have reinforced the importance of communication among personnel managers and nursing coordinators regarding detailed analysis and dynamics of the sectors with a focus on people management and sizing of the team ${ }^{(25)}$. Other research carried out in an ICU in São Paulo, Brazil, showed that the NAS had a significant negative correlation with the Braden scale, which assesses the risk of the patient developing a pressure ulcer ${ }^{(52)}$. However, the NAS was a protective factor for the occurrence of pressure ulcers in the sample. According to the authors, results indicate that the care provided is adequate in preventing injury and suggested that other risk factors, such as severity, length of stay in the ICU, and gender should be considered, as these variables contribute to the development of this type of injury ${ }^{(24)}$.

In most studies, results of this systematic review showed that nursing workload, analyzed by different instruments, had an impact on the occurrence of $\mathrm{AE}$ in patients during hospitalization in ICU. According to the literature, AE generate an impact on the quality of care, with increased rates of mortality, longer hospital stays and, consequently, higher welfare costs ${ }^{(53)}$. In this regard, the importance of analyzing the workload of nursing required by patients is necessary in order to establish a proper relationship between the number of nursing professionals and patients, focusing on the prevention of $\mathrm{AE}$ and ensuring patient safety.

\section{CONCLUSION}

The influence of nursing workload required by patients in intensive care was identified as a risk factor for the occurrence of the AE infection, pressure ulcers, and/or medication errors in six of the eight studies examined. In one investigation, workload was identified as a protective factor for pressure ulcer development.

Intensive care nurses must monitor the daily nursing workload required by patients, using the tools available in the literature, such as validated scales in the country, to measure this variable, and be attentive to those occurring in the unit due to work overload, because this can exert a negative influence on patient safety.

The results of this review reinforce the need to conduct multicenter studies, with larger samples and longer follow-up to strengthen the evidence of the relationship between nursing workload and the occurrence of different $\mathrm{AE}$ in intensive care.

\section{RESUMO}

Objetivo: Identificar evidências sobre a influência da carga de trabalho de enfermagem na ocorrência de eventos adversos (EA) em pacientes adultos internados em Unidade de Terapia Intensiva (UTI). Método: Revisão sistemática da literatura realizada nas bases de dados MEDLINE, CINAHL, LILACS, SciELO, BDENF e Cochrane de estudos em inglês, português ou espanhol, publicados até 2015. Os EA analisados foram infecção, úlcera por pressão (UPP), quedas e erros associados a medicamentos. Resultados: Das 594 pesquisas potenciais identificadas, oito compuseram a amostra final da revisão. O Nursing Activities Score - NAS (37,5\%) e o Therapeutic Intervention Scoring System - TISS (37,5\%) foram os instrumentos mais utilizados para avaliação da carga de trabalho de enfermagem. Seis pesquisas $(75,0 \%)$ identificaram influência da sobrecarga de trabalho na ocorrência de infecção, UPP e uso de medicamentos. Uma investigação identificou que o NAS foi fator de proteção para UPP. Conclusão: A carga de trabalho de enfermagem requerida por pacientes na UTI influenciou a ocorrência de EA, e os enfermeiros devem monitorar diariamente esta variável para garantir o correto dimensionamento da equipe e a segurança da assistência prestada.

\section{DESCRITORES}

Carga de Trabalho; Equipe de Enfermagem; Segurança do Paciente; Unidades de Terapia Intensiva; Revisão.

\section{RESUMEN}

Objetivo: Identificar evidencias acerca de la influencia de la carga laboral de enfermería en la ocurrencia de eventos adversos (EA) en pacientes adultos ingresados en Unidad de Cuidados Intensivos (UCI). Método: Revisión sistemática de la literatura llevada a cabo en las bases de datos MEDLINE, CINAHL, LILACS, SciELO, BDENF y Cochrane de estudios en inglés, portugués o español, publicados hasta 2015. Los EA analizados fueron infección, úlcera por presión (UPP), caídas y errores asociados con fármacos. Resultados: De las 594 investigaciones potenciales identificadas, ocho compusieron la muestra final de la revisión. El Nursing Activities Score - NAS $(37,5 \%)$ y el Therapeutic Intervention Scoring System - TISS (37,5\%) fueron los instrumentos más utilizados para evaluación de la carga laboral de enfermería. Seis investigaciones $(75,0 \%)$ identificaron influencia de la sobrecarga laboral en la ocurrencia de infección, UPP y uso de fármacos. Una investigación identificó que el NAS fue factor de protección para UPP. Conclusión: La carga laboral de enfermería requerida por pacientes en la UCI influenció la ocurrencia de EA, y los enfermeros deben monitorear a diario dicha variable a fin de asegurar el correcto dimensionamiento del equipo y la seguridad de la asistencia prestada.

\section{DESCRIPTORES}

Carga de Trabajo; Grupo de Enfermería; Seguridad del Paciente; Unidades de Cuidados Intensivos; Revisión. 


\section{REFERENCES}

1. Brasil. Ministério da Saúde. Portaria n. 3432, 12 de agosto de 1998. Estabelece critérios de classificação entre diferentes Unidades de Tratamento Intensivo - UTI [Internet]. Brasília; 1998 [citado 2016 fev. 16]. Disponível em: http://bvsms.saude.gov.br/bvs/saudelegis/ gm/1998/prt3432_12_08_1998.html

2. Boyle D, O'Connell D, Platt FW, Albert RK. Disclosing error and adverse events in the intensive care unit. Crit Care Med. 2006;34(5):1532-7.

3. Kohn LT, Corrigan JM, Donaldson MS; Committee on Quality of Health Care in America. To err is human: Building a Safer Health System. Washington: Institute of Medicine/National Academy Press; 2000.

4. World Health Organization (WHO). More than words: conceptual framework for the international classification for patient safety. Version 1.1. Final Technical Report. Geneva: WHO; 2009.

5. Brasil. Ministério da Saúde. Portaria n. 529, de $1^{\circ}$ de abril de 2013. Institui o Programa Nacional de Segurança do Paciente (PNSP) [Internet]. Brasília; 2013 [citado 2016 jan. 15]. Disponível em: http://www.saude.pr.gov.br/arquivos/File/OSEGURANCA_DO_PACIENTE/ Portaria5292013_1.pdf

6. Brasil. Ministério da Saúde. Portaria n. 1.377, de 9 de julho de 2013. Aprova os Protocolos de Segurança do Paciente [Internet]. Brasília; 2013 [citado 2016 jan. 15]. Disponível em: http://www.saude.pr.gov.br/arquivos/File/OSEGURANCA_DO_PACIENTE/portaria1377_2013.pdf

7. Brasil. Ministério da Saúde. Portaria n. 2.095, de 24 de setembro de 2013. Aprova os Protocolos Básicos de Segurança do Paciente [Internet]. Brasília; 2013 [citado 2016 jan 15]. Disponível em: http://www.saude.pr.gov.br/arquivos/File/OSEGURANCA_DO_PACIENTE/ portaria_2095_2013.pdf

8. Magalhães AMM, Riboldi CO, Agnol CMD. Planejamento de recursos humanos de enfermagem: desafio para as lideranças. Rev Bras Enferm [Internet]. 2009 [citado 2015 dez. 20];62(4):608-12. Disponível em: http://www.scielo.br/pdf/reben/v62n4/20.pdf

9. Laurell AC, Noriega M. Processo de produção de saúde: trabalho e desgaste operário. São Paulo: Hucitec; 1989. p.109-18.

10. Kirchhof ALC, Lacerda MR, Sarquis LMM, Magnago TSB, Gomes IM. Compreendendo cargas de trabalho na pesquisa em saúde ocupacional na enfermagem. Colomb Méd [Internet]. 2011 [citado 2015 dez. 23];42 Supl 1:113-19. Disponível em: http://www.bioline. org.br/pdf?rc11047

11. Tanos MAA, Massarollo MCKB, Gaidzinski RR. Dimensionamento de pessoal de enfermagem em uma unidade especializada em transplante de fígado: comparação do real com o preconizado. Rev Esc Enferm USP [Internet]. 2000 [citado 2015 nov. 15];34(4):376-82. Disponível em: http://www.scielo.br/pdf/reeusp/v34n4/v34n4a09

12. Queijo AF, Padilha KG. Nursing Activities Score (NAS): cross-cultural adaptation and validation to Portuguese language. Rev Esc Enferm USP [Internet]. 2009 [cited 2015 Dec 15];43(n.spe):1018-25. Available from: http://www.scielo.br/pdf/reeusp/v43nspe/en_a04v43ns.pdf

13. Aiken LH, Clarke SP, Cheung RB, Sloane DM, Silber JH. Educational levels of hospital nurses and surgical patient mortality. JAMA. 2003;290(12):1617-23.

14. Needleman J, Buerhaus P, Matte S, Stewart M, Zelevinsky K. Nurse-staffing levels and the quality of care in hospitals. N Engl J Med. 2002;346(22):1715-22.

15. Kiekkas P, Sakellaropoulos GC, Brokalaki H, Manolis E, Adamantios S, Skartsani C, et al. Association between nursing workload and mortality of Intensive Care Unit patients. J Nurs Scholarsh. 2008;40(4):385-90.

16. Galvão CM, Sawada NO, Trevizan MA. Revisão sistemática: recurso que proporciona a incorporação das evidências na prática da enfermagem. Rev Latino Am Enfermagem [Internet]. 2004 [citado 2016 jan. 5];12(3):549-56. Disponível em: http://www.scielo.br/pdf/ rlae/v12n3/v12n3a14.pdf

17. Santos CMC, Pimenta CAM, Nobre MRC. The PICO strategy for the research question construction and evidence search. Rev Latino Am Enfermagem [Internet]. 2007 [cited 2015 Oct 15];15(3):508-11. Available from: http://www.scielo.br/pdf/rlae/v15n3/v15n3a23.pdf

18. Malta M, Cardoso LO, Bastos FI, Magnanini MMF, Silva CMFP. STROBE initiative: guidelines on reporting observational studies. Rev Saúde Pública [Internet]. 2010 [cited 2015 Nov 7];44(3):559-65.Available from: http://www.scielo.br/pdf/rsp/v44n3/en_21.pdf

19. Ferrada S, Urso A, Riffo C, Sánchez H, Villamizar G. Relación entre carga laboral e incidentes em una unidad de cuidados intensivos polivalente. Rev Chil Med Intensive 2005;20(2):87-90

20. Blatnik J, Lesnicar G. Propagation of methicillin-resistant Staphylococcus aureus due to the overloading of medical nurses in intensive care units. J Hosp Infect [Internet]. 2006;63(2):162-66.

21. Celen MK, Tamam Y, Hosoglu S, Ayaz C, Geyik MF, Apak I. Multiresistant bacterial colonization due to increased nurse workload in a neurology intensive care unit. Neurosciences. 2006;11(4):265-70.

22. Seynaeve S, Verbrugghe W, Claes B, Vandenplas D, Reyntiens D, Jorens PG. Adverse drug events in intensive care units: a cross-sectional study of prevalence and risk factors. Am J Crit Care. 2011;20(6):131-40.

23. Daud-Gallotti RM, Costa SF, Guimarães T, Padilha KG, Inoue EN, Vasconcelos TN, et al. Nursing workload as a risk factor for healthcare associated infections in ICU: a prospective study. PLoS ONE [Internet]. 2012 [cited 2015 Sep 20];7(12):e52342. Available from: http:// www.ncbi.nlm.nih.gov/pmc/articles/PMC3531467/

24. Cremasco MF, Wenzel F, Zanei SSV, Whitaker IY. Pressure ulcers in the intensive care unit: the relationship between nursing workload, illness severity and pressure ulcer risk. J Clin Nurs. 2013;22(15-16):2183-91.

25. Novaretti MCZ, Santos EV, Quitério LM, Daud-Gallotti RM. Sobrecarga de trabalho da Enfermagem e incidentes e eventos adversos em pacientes internados em UTI. Rev Bras Enferm [Internet]. 2014 [citado 2015 set. 20];67(5):692-9. Disponível em: http://www.scielo.br/ pdf/reben/v67n5/0034-7167-reben-67-05-0692.pdf

26. Aycan IO, Celen MK, Ayhan Y, Mehmet AS, Tuba D, Celik Y, et al. Bacterial colonization due to increased nurse workload in an intensive care unit. Braz J Anesthesiol. 2015;65(3):180-85.

27. Miranda DR, Nap R, de Rijk A, Schaufeli W, lapichino G. Nursing activities score. Crit Care Med. 2003;31(3):374-82 
28. Coelho FUA, Queijo AF, Andolhe R, Gonçalves LA, Padilha KG. Carga de trabalho de enfermagem em unidade de terapia intensiva de cardiologia e fatores clínicos associados. Texto Contexto Enferm [Internet]. 2011 [citado 2016 jan. 4];20(4):735-41. Disponível em: http:// www.scielo.br/pdf/tce/v20n4/12.pdf

29. Gonçalves LA, Garcia PC, Toffoleto MC, Telles SCR, Padilha KG. Necessidades de cuidados de enfermagem em Terapia Intensiva: evolução diária dos pacientes segundo o Nursing Activities Score (NAS). Rev Bras Enferm [Internet]. 2006 [citado 2016 jan. 10];59(1):56-60. Disponível em: http://www.scielo.br/pdf/reben/v59n1/a11v59n1.pdf

30. Balsanelli AP, Cunha ICKO, Whitaker IY. Nurses leadership styles in the ICU: association with personal and professional profile and workload. Rev Latino Am Enfermagem [Internet]. 2009 [cited 2016 Jan 10]; 17(1). Available from: http://www.scielo.br/pdf/rlae/v17n1/05.pdf

31. Adell AB, Campos RA, Cubedo RM, Quintana BJ, Sanahuja RE, Sanchís MJ, et al. Nursing Activity Score (NAS): our experience with a nursing load calculation system based on times. Enferm Intens. 2005;16(4):164-73.

32. Adell AB, Campos RA, Bou MY, Bellmunt JQ, Garcia CG, Canuto MS, et al. Care workload in critical patients: comparative study NEMS versus NAS. Enferm Intens. 2006;17(2):67-77.

33. Stafseth SK, Solms D, Bredal IS. The characterisation of workloads and nursing staff allocation in intensive care units: a descriptive study using the Nursing Activities Score for the first time in Norway. Intensive Crit Care Nurs. 2011;27(5):290-4.

34. Conselho Federal de Enfermagem. Resolução n. 293, de 21 de setembro de 2004. Fixa e Estabelece Parâmetros para o Dimensionamento do Quadro de Profissionais de Enfermagem nas Unidades Assistenciais das Instituições de Saúde e Assemelhados [Internet]. Brasília; 2004 [citado 2016 jan. 15]. Disponível em: http://www.cofen.gov.br/resoluo-cofen-2932004_4329.html

35. Cullen DJ, Civetta JM, Briggs BA, Ferrara LC. Therapeutic Intervention Scoring System: a method for quantitative comparison of patient care. Crit Care Med. 1974;2(2):57-60.

36. Miranda DR, de Rijk A, Schaufeli W. Simplified Therapeutic Intervention Scoring System: the TISS-28 itens - results from a multicenter study. Crit Care Med. 1996;24(1):64-73.

37. Saulnier F, Duhamel A, Descamps JM, de Pouvourville G, Durocher A, Blettery B, et al. Indicateur simplifé de la charge en soins spécifique à la réanimation: le PRN réa. Réan Urg. 1995;4(5):559-69.

38. France. Comission d'Évaluation de la Société de Réanimation de Langue Française. Utilisation de Lindice de gravité simpliflié et du systéme OMEGA. Réan Soins Intens Méd Urg. 1986;2:219-21.

39. Oliveira MAP, Parente RCM. Estudos de coorte e de caso-controle na era da medicina baseada em evidência [editorial]. Bras J Video-Sur [Internet]. 2010 [citado 2016 jan. 3]; 3(3):115-25. Disponível em: http://sobracil.org.br/revista/jv030303/bjvs030303_115.pdf

40. Souza ES, Belei RA, Carrilho CMDM, Matsuo T, Yamada-Ogatta SF, Andrade G, et al. Mortality and risks related to healthcare-associated infection. Texto Contexto Enferm [Internet]. 2015 [cited 2016 Jan 15];24(1):220-8. Available from: http://www.scielo.br/pdf/tce/ v24n1/0104-0707-tce-24-01-00220.pdf

41. Brasil. Ministério da Saúde. Protocolo para a prática de higiene das mãos em serviço de saúde [Internet]. Brasília; 2013 [citado 2016 mar. 02]. Disponível em: http://www.saude.pr.gov.br/arquivos/File/OSEGURANCA_DO_PACIENTE/protocolo_higiene_das_maos.pdf

42. Schwab F, Meyer E, Geffers C, Gastmeier P. Understaffing, overcrowding, inappropriate nurse: ventilated patient ratio and nosocomial infections: which parameter is the best reflection of deficits? J Hosp Infect. 2012;80(2):133-9.

43. Hugonnet S, Uçkay I, Pittet D. Staffing level: a determinant of late-onset ventilator-associated pneumonia. Crit Care. 2007;11(4):R80.

44. Aspden P, Wolcott J, Bootman JL, Cronenwett LR; Committee on Identifying and Preventing Medication Errors. Preventing medication errors: quality chasm series.Washington: National Academies Press; 2007.

45. Beccaria LM, Pereira RAM, Contrin LM, Lobo SMA, Trajano DHL. Nursing care adverse events at an intensive care unit. Rev Bras Ter intensiva [Internet]. 2009 [cited 2016 Jan 6];21 (3):276-82. Available from: http://www.scielo.br/pdf/rbti/v21n3/en_a07v21n3.pdf

46. Toffoletto MC, Padilha KG. Consequências dos erros de medicação em unidades de terapia intensiva e semi-intensiva. Rev Esc Enferm USP [Internet]. 2006 [citado 2016 jan. 7];40(2):247-52. Disponível em: http://www.scielo.br/pdf/reeusp/v40n2/12.pdf

47. Brasil. Ministério da Saúde. Protocolo de segurança na prescrição, uso e administração de medicamentos [Internet]. Brasil; 2013 [citado 2016 Mar 02]. Disponível em: http://www.saude.pr.gov.br/arquivos/File/OSEGURANCA_DO_PACIENTE/ PROTOCOLOSEGURANAMEDICAMENTOSA.pdf

48. Rohde JM, Myers AH, Vlahov D. Variation in risk for falls by clinical department: Implications for prevention. Infect Control Hosp Epidemiol. 1990;11(10):521-4.

49. Silva MLN, Caminha RTO, Oliveira SHS, Diniz ERS, Oliveira JL, Neves VSN. Úlcera por pressão em unidade de terapia intensiva: análise da incidência e lesões instaladas. Rev Rene [Internet]. 2013 [citado 2016 jan. 15];15(5):938-44. Disponível em: http://www.revistarene. ufc.br/revista/index.php/revista/article/view/1341

50. Matos LS, Duarte NLV, Minetto RC. Incidência e prevalência de úlcera por pressão no CTI de um Hospital Público do DF. Rev Eletr Enf [Internet]. 2010 [citado 2016 jan. 18];12(4):719-26. Disponível em: https://www.fen.ufg.br/fen_revista/v12/n4/pdf/v12n4a18.pdf

51. Manzano F, Navarro MJ, Róldan D, Moral MA, Leyva I, Guerrero C, et al. Pressure ulcer incidence and risk factors in ventilated intensive care patients. J Crit Care. 2010;25(3):469-76.

52. Paranhos WY, Santos VLG. Avaliação de risco para úlceras de pressão, utilizando a Escala de Braden em Português. Rev Esc Enferm USP. 1999;33(n.esp):191-204.

53. Ventura CMU, Alves JGB, Meneses JA. Eventos adversos em Unidade de Terapia Intensiva Neonatal. Rev Bras Enferm [Internet]. 2012 [citado 2016 fev. 10];65(1):49-55. Disponível em: http://www.scielo.br/pdf/reben/v65n1/07.pdf 